\title{
On the Three Dimensional Model of the Practical Teaching of Finance and Economics in Higher Vocational Colleges
}

\author{
Wan Daili \\ Chongqing business vocational college \\ Chongqing, China
}

\begin{abstract}
Professional is very common in higher vocational colleges of finance and economics is a professional, practical strong, qualified teachers in colleges and universities in the modern enterprise to put forward the higher request, requests the student in the first in the enterprise can quickly into the work, therefore in the process of teaching cannot be separated from practice, practice teaching has very important significance. Higher vocational college of finance and economics majors should build scientific practice teaching mode, to improve the effect of practice teaching, cultivating financial professional high-quality talent.
\end{abstract}

Keywords - financial professional; Practice teaching; Three-dimensional model

\section{THE INTRODUCTION}

As the financial professional students employment pressure is more and more big, the financial professional must change the traditional teaching way in the past, build a practical teaching system, so as to cultivate meet the market demand for financial talents. At the time of constructing practice teaching system should be clear the aim of training professional talents of finance and economics, to improve the students' comprehensive professional quality, at the same time of improving students' technical also pay attention to the cultivation of the students practical and applied, so as to cultivate applied talents, improve the students' employment rate.

\section{THE PRACTICAL TEACHING OF FINANCE AND ECONOMICS CONSTRUCTION OF THREE-DIMENSIONAL MODEL}

\section{A. The teaching aim of practice teaching}

According to financial professional talent training target, the construction of practice teaching model of three-dimensional should first be sure that the professional training of finance and economics teaching goal, the ultimate goal of talent cultivation is the students' employment, along with the social demand for talents is more and more high, schools require students to master the basic skills and basic knowledge, should innovate their own thinking, training students' practical ability to solve problems. Students only have a certain ability to solve practical problems, can quickly adapt to the society, on entering the society into the financial and economic work. With the continuous development of society, modern society has already marched into the era of diversification, the employment problem of graduates in colleges and universities has become a major problem, in order to improve the students' employment, also requires schools to continuously enhance the comprehensive quality of students [1]. Due to the continuous development of market economy, as a financial professional students, master professional knowledge and skills is the most basic requirement, but it is not enough to only professional knowledge, at the same time for their industry and market also to have certain understanding. In addition, the general enterprises in recruiting talents require job seekers have certain practical ability, so the study of finance in the practice teaching is very necessary, can improve students' ability of "work-integrated learning".

\section{B. The teaching content of practice teaching}

\section{1) Professional skills}

For financial professional students, in the process of practice teaching should also be very pay attention to the cultivation of students' professional skills and improving, any practical activity is inseparable from the learning of theoretical knowledge and practical training teaching not only can't out of the study of theoretical knowledge, at the same time should also and theories teaching complement each other, let the students master the practical teaching in the process of theory of knowledge learning to master the knowledge, in the process of practice teaching and can further improve their professional knowledge. In the process of professional skills training teaching, require students to master the basic knowledge of management, economics and statistics, and so on, and these knowledge and their own professional knowledge to achieve mastery through a comprehensive study. Modern society put forward higher demand for talents, attaches great importance to talented person's comprehensive ability, students only with reasonable knowledge structure can be social need, for financial professional students, students need to master not only solid basic knowledge and basic skills, but also should master and finance related professional knowledge, such as marketing, computer, accounting, management, etc. If it is too much emphasis on the students' professional knowledge of teaching, students of related knowledge is not known, it is very conducive to the students' innovation, cultivate the students though have professional knowledge, but at the same time the overall knowledge structure is single, students practical ability to solve problems cannot be improved.

\section{2) Professional quality}

As a financial professional students, the students' professional quality education has a very important role, professional quality education including the concept of professional ethics, professional, innovation, quality, etc., need to strengthen students' awareness of professional at 
the same time, let the students can really fall in love with their own professional, and is willing to join in their professional work. So in the process of practice teaching in the teaching, the student just entering the university should strengthen the student's professional, to carry out career planning curriculum, let the students in college to start planning their own career. After students have mastered some professional knowledge, the school should through training practice teaching to simulate a real office, arrange students to field work, or through the university-enterprise cooperation to improve students' contact with the actual position and job opportunities, to cultivate students' good professional quality.

\section{3) Develop skills}

In the professional training of finance and economics teaching, in addition to the cultivation of professional skills, professional quality, it should improve to the attention of the students to develop skills. In the teaching process should pay attention to the development of students' knowledge of theory and practice guidance, but the reality is that although most of the colleges and universities have realized the importance of practice teaching, but all the practice activities, including university-enterprise cooperation, field work, etc., usually only professional practice, attach importance to the remains of the students' professional knowledge, students into the enterprise, and put all the energy in the financial aspects of the work, students lack of opportunity is an all-round understanding of design company's daily management and operation mode, etc., for customer resources and business channels is still not understand, social practice did not play its proper role [2]. Develop skills education should encourage students to 1 to 2 doors for inter-disciplinary study different skills, pay attention to cultivation of talents.

\section{FINANCIAL PROFESSIONAL PRACTICAL TEACHING METHOD}

\section{A. Case teaching method}

Case analysis method under the guidance of teachers, through the analysis of actual case guide the student to carry on the omni-directional thinking and observation to the given material, ask students to actively participate in the learning process, to improve the students' ability of autonomous learning, analysis the problem, and then use learned knowledge put forward effective countermeasures, finally make the right judgment and decision making. Case analysis teaching through a case simulation to let the students contact the economic practice of teaching, which is one of the simplest to use theoretical knowledge to solve practical problems in the actual a method of teaching can inspire students' thinking, let students learn knowledge to practice, so as to enhance students' ability of using knowledge, at the same time can also make students truly understand the practicability of finance and economics. In this process, the students' ability of independent analysis got the training, at the same time can also be used to study the theoretical knowledge to solve practical problems. Teachers in the use of case teaching method in teaching, can't choose too mechanization and simple case, the selected case should be consistent and the practical social economic life. If teachers at the time of using case teaching method still didn't change the past that kind of light practice of legal thoughts, the role of case teaching method still can not get to play [3].

\section{B. Simulation teaching method}

Simulation teaching through student playing the role of sales, material accounting, cost accounting, tax accountant and cashier, such as the role of specific, let the students to apply their learned knowledge truly professional practice to people. The simulation teaching is the students' abilities of empirical study and reflection, the difference between it and the traditional teaching mode is to pay more attention to the students' self learning ability, because in the actual operation process, all the characters are all students play, teacher's role is to lead and guide the students [4]. Through practice of specific professional simulation, can make the students master more economic operation skill, to improve students' practical ability to run. Simulation teaching more convenient operation, on training teachers or school interior can be performed, according to the teaching content to create a specific environment, then the students by acting as the real financial position to operate, to learn the theoretical knowledge and practical operation, to teach students theoretical knowledge also can teach practical operation experience, cultivate the students' practical ability, and at the same time in the simulation of solving the problem to improve the understanding of theoretical knowledge [5].

\section{Project oriented teaching method}

Project oriented teaching method is surrounding the professional ability of students for teaching, will finance professional course study is divided into a number of projects, and scientific design and select the project, finally formed a complete teaching plan, improve the students' knowledge structure and improve student's quality structure and ability structure. In the process of project teaching, each project of teaching are just combined with actual jobs. In accounting professional teaching process, for example, can be combined audit accounting vouchers and accounting manager position, make each project can be combined with the practical work of teaching, make students with real task. Project oriented teaching method is a kind of exploratory teaching pattern, in the process of the teaching can cultivate students' ability of independent analysis problem, teachers guide students from simple to difficult, step by step to complete a series of project learning, and for every project learning can be familiar with the master, the students after entering the society can according to their own practical experience in the learning process into work quickly to [6]. In addition, schools should also make full use of off-campus practice base, many colleges and universities have been set up in all financial professional enterprises, financial industry and the practice base for accounting firm, schools can organize regular on-site teaching students, in a planned way to lead students to the foundations of visiting and training, improve the students' perceptual knowledge in professional, so as to achieve good teaching effect. 


\section{CONCLUSION}

In order to meet the social demand for finance professionals, higher vocational colleges should build effective stereoscopic practice teaching mode, according to the characteristics of students' professional practical teaching goal, for sure, and according to the goal of practical teaching innovation of practice teaching method and content, through case teaching, simulation teaching method and project oriented teaching method such as effective methods for teaching, in the process of teaching students to increase students and post, occupational exposure, cultivate comprehensive applied talents.

\section{REFERENCE}

[1] Chen Shangjin. The innovation of higher vocational talents training mode of financial and economics in exploring $[\mathrm{J}]$. Journal of chifeng institute, 2014, 25 (2) : 204-205.
[2] zhang hong, small wan liang. Business model of higher vocational education reform path analysis $[\mathrm{J}]$. Journal of China higher education research, 2013, 4 (6) : 97-98.

[3] li. Modular of vocational professional group of practice teaching course system of finance and economics research $[\mathrm{J}]$. Journal of sichuan vocational and technical college, 2012, 21 (6) : 114-115.

[4] Chen Rui. Analyses the direction of the reform of curriculum system in higher vocational colleges and strategy [J]. Journal of changchun college of education, 2013,52 (8) : 132.

[5] lily, BaoQing. The building of higher vocational professional training of finance and economics teaching three-dimensional model [J]. Journal of anhui police vocational college journal, 2015 (52) : 95-97.

[6] janet, haiyan shui. Higher vocational categories of professional practice teaching reform of finance and economics research $[\mathrm{J}]$. Journal of cooperation in economy and technology, 2013, 24 (12) : 111. 